\title{
EFL STUDENTS' PERFORMANCE AND EXPECTATION TOWARDS PEER RESPONSE IN WRITING CLASSROOM
}

\author{
M. Zaini Miftah \\ State Islamic Institute of Palangka Raya, Central Kalimantan, Indonesia \\ (miftahmzaini@gmail.com)
}

Received: $23^{\text {th }}$ September 2016; Revised: $22^{\text {th }}$ November 2016; Accepted: $28^{\text {th }}$ Desember 2016

\section{ABSTRACT}

This study investigates the EFL students' performance and expectation towards peer response in writing classroom. A survey research method was applied. Data were collected through a questionnaire containing 20 items. The questionnaire was distributed to 12 Indonesian EFL students enrolling in a writing course at the English Department of IAIN (State Islamic Institute) Palangka Raya, Central Kalimantan, Indonesia. The findings of the study showed that the tendencies of the tasks performed by the student reviewers are asking about peers' ideas and meanings of their essays, of the student-writers responses to peer response are paying attention to clear correction and correcting mechanical errors, and of the student-writers expectations from the peer response are commenting on ideas and meanings, providing clear corrections, and correcting mechanical errors.

Key Words: EFL students; peer response; student-reviewers performance; student-writers response; student-writers expectation

\begin{abstract}
ABSTRAK
Penelitian ini mengkaji performa dan harapan mahasiswa dalam konteks EFL terhadap respon teman sejawatnya dalam kelas menulis. Metode penelitian survey diterapkan dalam penelitian ini. Data dikumpulkan menggunakan kuesioner dengan 20 pertanyaan. Kuesioner ini diberikan kepada 12 mahasiswa EFL di Indonesia pada kelas menulis Prodi Pendidikan Bahasa Inggris IAIN (Institut Agama Islam Negeri) Palangka Raya, Kalimantan Tengah, Indonesia. Sebagai hasil dari penelitian, terlihat bahwa kecenderungan tugas yang dilakukan oleh mahasiswa sebagai penyunting adalah bertanya tentang ide-ide dan makna dari esai teman sejawatnya, kecenderungan tanggapan dari mahasiswa sebagai penulis terhadap respon teman sejawat adalah memperhatikan koreksi yang jelas dan mengoreksi kesalahan mekanik, dan kecenderungan harapan mahasiswa sebagai penulis terhadap respon teman sejawat yaitu mengomentari ide dan makna, memberikan koreksi yang jelas, dan juga mengoreksi kesalahan mekanik dari esai teman sejawatnya.
\end{abstract}

Kata Kunci: Mahasiswa EFL; respon teman sejawat; performa mahasiswa penyunting; respon mahasiswa penulis; harapan mahasiswa penulis

How to Cite: Miftah, M., Z. (2016). EFL Students' Performance and Expectation Towards Peer Response in Writing Classroom. IJEE (Indonesian Journal of English Education), 3(2), 208-223 doi:10.15408/ijee.v3i2.5513.

Permalink/DOI: http:/ /dx.doi.org/10.15408/ijee.v3i2.5513 


\section{INTRODUCTION}

Writing has always been considered as an important skill in the teaching and learning of English as a Foreign Language (EFL) (Luchini, 2010). It inspires logical thinking, pushes students to focus on their attention, sorts out their ideas, and develops their ability to summarize, analyze and criticize. It also enhances learning by thinking in and reflecting on the target language. However, most students find it difficult to compose a text in forms of paragraph or essay because the writing process requires particular strategies of which they are mostly unaware.

While most EFL teachers are frequently puzzled by these problems in their writing classes, they cannot find a resourceful way to arouse their students' creativity and put their minds to work effectively (Rao as cited in Luchini, 2010). Given this context of the situation, many EFL teachers in Indonesia realize that writing is a problem for their students. The majority of teachers find it difficult to help their students, and sometimes, even though there has been a thorough preparation, the activities they try to use in the writing lesson do not always work well on their students' achievements of writing. Therefore, in an attempt to introduce approaches and classroom activities that promote language learning, typically writing skills, writing teachers employ many different approaches and techniques. One such technique is the use of peer response in the writing instruction.

Bell (1991) pointed out that current composition theory supports the use of peer response focusing on the writing process more than the written product. It has created the process approach to teaching writing. The process approach itself benefits students greatly for the development of their writing. As confirmed by a research on the implementation of the process approach in writing classroom, it is revealed that the process writing approach with proper model procedures could enhance students' writing skills (Miftah, 2015). Additionally, in response to the impact of collaborative learning theory and a shift in the teaching of writing with an emphasis on the product to an emphasis on process, peer response has gained its popularity in writing classes (Nelson \& Murphy as cited in Widiati, 2003). Thus, peer response is supported by several theoretical frameworks, including process writing and collaborative learning.

\section{According to Mangelsdorf} (1992), peer response technique is sometimes called peer editing, peer 
evaluation or peer review. In this activity, students do more than editing, evaluating or reviewing students' essays. They are responding to what the essay says as well as how it says it. For beginning EFL students, peer response sessions usually consist of a group of three or four students reading or listening to a peer's draft and commenting on what they found most interesting, what they wanted to know more about, where they were confused, and so on-the types of response that naturally emerge from a discussion of writer's ideas. Therefore, the student writers use the peers' feedback or responses to decide how to revise their drafts.

About a process of reviewing, Flower and Hayes as cited in Hapsari (2015) suggested that a review process through peer response activities, for instance, is not the final activity of a writing process. The review process may bring the writers to the new or next planning or pour their ideas into written text. Thus, a review process in peer response activities does not take place only once, but it can take several times leading the student writers to produce better writings.

Mangelsdorf (1992) added that at beginner and advanced levels of instruction, students can use a worksheet or peer response sheet to answer questions concerning the draft's thesis, unity, development, focus, and so forth-whatever teacher wants to emphasize for that particular focus of lesson-as detailed as possible. Thus, after students complete the peer response sheet for a peer's draft, they then discuss with their peers the suggestions they made for revision.

Furthermore, Stevens and Levi (2005) indicated that peer response or feedback is most effective when given as soon as the student writers complete their drafts in order to help them make positive changes in their subsequent work in the writing process. However, once the peer response process is underway, the writers' perception of the value of the enterprise is likely to change if they begin to receive useful feedback (Rollinson, 2005). For this to happen, however, the writing course has to be set up properly with the prior plan of grouping-peer group response and its procedure.

Referring the advantage of peer response in writing class, Mittan as cited in Mangelsdorf (1992) pointed out that peer response can provide students with an authentic audience, increase their motivation for writing, enable students to receive different views of their writings, help students learn to critically read their own writings, and assist students in gaining confidence in 
their writings, and, by discussions, it allows students to use oral language skills. In short, peer response has the potential to be a powerful learning tool or technique.

The use of peer response or feedback is one means of making the function of assessments formative (Askew, 2000). Moreover, Sadler as cited in Askew (2000, p. 21) asserts that if peer response feedback does not have a formative effect on learning, then it is not true feedback. In this context, the formative effect on learning means that the student writers' learning process using peer response is formed into a more developed process of writing typically in the revising and editing stages. To sum up, as writing teachers have begun to recognize the need to provide support for students at each stage of the writing process, the use of peer response has become increasingly popular.

Dealing with peer response used in the writing process, Salih (2013, ) indicated that peer response has been regarded an essential feedback delivery system in a process-based second language (L2) writing classroom. The essence of collaborative process-based writing is the creation of instances of feedback by peers. Indeed, peer response provides an opportunity for peers to develop criteria for evaluation and to practice giving their own written feedback and that of others.

Peer response can be implemented with the integrated ways through online activities such as Facebook (Miftah, 2014) and blogging activities (Miftah, 2016). The findings showed that peer response via Facebook could be implemented in writing class (Miftah, 2014). Other findings reported that blogging activities could promote students' writing abilities in which the activity using weblogs was combined with faceto-face learning mode with writing instruction implementing the process writing approach and peer response (Miftah, 2016).

Many studies have been conducted to investigate peer response in ESL/EFL writing classroom. Some studies reported on investigating the value of peer response in writing class (Mangelsdorf, 1992; Tang \& Tithecott, 1999). Other studies revealed that peer response gave positive impacts on writing skill (Wakabayashi, 2008; AlJamal, 2009; Farrah, 2012; Jahin, 2012). Next studies were investigating the quality, types, and focus on peer response on L2 writing process (Ting \& Qian, 2010; Salih, 2013). Meanwhile, in the Indonesian EFL context, some studies had been successfully investigated peer response in the 
teaching of writing (Widiati, 2003; Mubarak, 2009; Miftah, 2014; Miftah, 2015). However, studies on peer response need further exploration, specifically in the context of EFL writing teaching.

In the Indonesian EFL writing classroom, particularly in English Department of IAIN (State Islamic Institute) Palangka Raya, Central Kalimantan, Indonesia, peer response needs investigation. There are still questions regarding what students' do in peer response and what they hope from peer response. The suitability between peer response and the studentwriter expectation is also the concerns of this paper. Therefore, it is very much necessary to do a research investigating EFL students' performance in and expectation of peer response in writing classroom, more specifically investigating the tasks performed by the student reviewers, the studentwriters response to peer response, and the student-writers expectation to peer response.

This current study is thus conducted to provide proof of the implementation of peer response related to the students' performance in and expectation of peer response in EFL writing classroom. This article reports results of a survey which is part of a broader case study on peer response in an Indonesian EFL writing class (Miftah, 2015). Therefore, specifically, this research tries to investigate the following set of questions: (1) How do the EFL students' perform in a peer response activity?. (2) What do the EFL students expect from a peer response?

\section{METHOD}

In order to explore the performance and expectation of the EFL students towards peer response in writing classroom, a survey research method was applied. The questionnaire was distributed to 12 Indonesian EFL students who enrolled in the class of Writing III Course, particularly in the English Department of IAIN (State Islamic Institute) Palangka Raya, Central Kalimantan, Indonesia. The number of participants was chosen under the consideration that they get involved in the peer response activities led by the teacher in the writing classroom-Writing III course. Therefore, all students were selected to be the participants or the population sample of the study.

To collect the data, a questionnaire with closed-ended questions was distributed to the participants. The steps were that preparing the questionnaire, giving the questionnaire to the participants, 
collecting the responses, calculating the result of responses, analyzing the data obtained, and finally concluding the results by referring to the objective of the study. The data-gathering through questionnaire is done by asking the students rather than by observing and sampling their behavior (Tuckman, 1999).

A questionnaire containing 20 items adapted from a similar research was used for data collection. The questionnaire was completed by the students in about 15 minutes. Of the 20 items, 7 items asked the kinds of tasks performed by student reviewers, 6 items pertained to how student-writers response to peer response, and 7 items investigated what student-writers expect from peer response. Each question item has five possible responses - strongly agree (SA), agree $(\mathrm{A})$, uncertain $(\mathrm{U})$, disagree $(\mathrm{D})$, and strongly disagree (SD). The informants were told to choose the items they preferred by giving a check mark $(\sqrt{ })$ in the box. Selecting a particular option by a respondent determines the degree of agreement or disagreement, and thus reveals how the respondents perceive the issue the statements discussed. The questionnaire was distributed to the participants after they had completed the peer response activities in the writing classroom, and this was later collected for further analysis.

Data were analyzed using descriptive statistics of frequency counts and percentage. They were counted into percentage and coded to classify the EFL students' performance in and expectation of peer response in writing classroom. As suggested by McKay (2008), in a survey research, coding strategy is the first thing to do. Data were categorized into three categories by calculating questionnaire frequency count and percentage equivalent. They were the studentreviewers questionnaire frequency count and percentage equivalent, the questionnaire frequency count of the student-writers response to peer response and percentage equivalent, and the questionnaire frequency count of the student-writers expectation from peer response and percentage equivalent.

\section{FINDINGS AND DISCUSSION}

The analysis of the questionnaire showed interesting findings. To discuss the data more specifically, data obtained from the questionnaire were analyzed and displayed separately. 


\section{The EFL Students' Performance in}

\section{Peer Response}

Tasks Performed by the Student Reviewers

Table 1 shows the studentreviewers questionnaire frequency count and percentage equivalent. It shows the respondents' score on tasks reviewers that had to do with the peer response activities.

It shows that in responding to item (1), $25 \%$ of the participant strongly agreed and $75 \%$ agreed that they asked student writers about their ideas and meanings of their essays. The result reveals that all of the reviewers asked the writers for clarification regarding the ideas and meanings of their essays.

Item (2) in the questionnaire was about the students focus when they evaluated their peers' drafts. The students were asked about if they focused on grammar accuracy correction as the main area in the peer response activities. The analysis showed that $50 \%$ strongly agreed and $42 \%$ agreed that they mainly focused on grammatical errors in the peers' drafts. On the other hand, $8 \%$ of the participants expressed uncertainty about their stand. It indicates that most of the reviewers mainly focused on grammar accuracy correction.

The analysis of item (3) in the questionnaire revealed that $17 \%$ of the students strongly agreed and 75\% agreed that they commented on their peers' ideas and meanings and extend them as well. On the other hand, $8 \%$ of the respondents remained uncertain about their contribution to the writers' ideas development. It is said that the reviewers mostly commented on their peers' ideas and meanings and extend them as well.

Table 1: Tasks Performed by the Student Reviewers

\begin{tabular}{|c|c|c|c|c|}
\hline \multirow[t]{2}{*}{ Statement } & \multicolumn{4}{|c|}{ Frequency (Percentages) } \\
\hline & SA & A & $\mathrm{U}$ & D SD \\
\hline $\begin{array}{l}\text { 1) I ask about peers' ideas and meanings of } \\
\text { their essays. }\end{array}$ & $3(25 \%)$ & $9(75 \%)$ & & \\
\hline 2) My review focuses on grammar accuracy. & $6(50 \%)$ & $5(42 \%)$ & $1(8 \%)$ & \\
\hline $\begin{array}{l}\text { 3) I give comment on peers' ideas and } \\
\text { meanings and extend them. }\end{array}$ & $2(17 \%)$ & $9(75 \%)$ & $1(8 \%)$ & \\
\hline $\begin{array}{l}\text { 4) I provide a set of clear correction by giving } \\
\text { symbols. }\end{array}$ & $5(42 \%)$ & $5(42 \%)$ & $2(17 \%)$ & \\
\hline $\begin{array}{l}\text { 5) I evaluate peers' vocabulary use and } \\
\text { suggest corrections. }\end{array}$ & $3(25 \%)$ & $7(58 \%)$ & $2(17 \%)$ & \\
\hline 6) I evaluate peers' essay structure. & $4(33 \%)$ & $6(50 \%)$ & $2(17 \%)$ & \\
\hline 7) I give correction for mechanical errors. & $4(33 \%)$ & $7(58 \%)$ & $1(8 \%)$ & \\
\hline
\end{tabular}


Item (4) in the questionnaire explored the participants' perceptions about the clarity of their response to peers' writing and ideas. The results showed that $42 \%$ strongly agreed and $42 \%$ agreed that they provided a set of clear corrections by giving review symbols to peer's drafts. For the same task, $17 \%$ of the participants answered uncertain about their correction and review symbols to the drafts. It means that majority of the reviewers provided a set of clear corrections by giving review symbols to peer's drafts. This result suggests that the students have developed a positive attitude toward peer response activities.

The table also reveals that $25 \%$ of the participants strongly agreed and $58 \%$ agreed that they evaluated peers' vocabulary use and suggested the corrections while $17 \%$ were uncertain with a focus on vocabulary (item 5). Additionally, the table shows that in responding to item (6) $33 \%$ of the respondents strongly agreed and 50\% agreed that they evaluated their peers' essay structure. On the other hand, 17\% of the students expressed uncertainty about their evaluation to their peers' essay structure.

The analysis of item (7) of the questionnaire also showed that $33 \%$ of the participants strongly agreed and
$58 \%$ agreed that they focused on correction of mechanical errors in the peer response activity, while $8 \%$ wasfound uncertain.

In short, from overall results, as indicated in Table 1, it was obvious that most participants had positive contribution to the peer response activities. Most the student reviewers showed a positive statement of each item towards peer response, particularly related to the advice or review on ideas and meanings of an essay, grammar accuracy, way of giving correction, vocabulary use, essay organization, and correction for a mechanic. Such finding is similar to the research finding of the former study conducted by Salih (2013). The findings of the former study revealed that the feedback providers' tendency and focus when reviewing peer drafts were in the areas of above items.

However, the kinds of tasks that the student reviewers tend to do were asking about peers' ideas and meanings of their essays. It is indicated from the total of the student-reviewers questionnaire frequency count and percentage equivalent from strongly agreed (SA) and agreed (A) to item (1), totally $100 \%(n=12)$. 
The Student-Writers Response to Peer Response

Table 2 shows the questionnaire frequency count of the student-writers response to peer response and its percentage equivalent. It indicates the respondents' score on the writer response to peer response on essay drafts.

The analysis of the questionnaire has also focused on specific areas of writer response to peer response: rereading the ideas and meanings of an essay, correcting grammatical errors, paying attention to a set of clear correction and review symbols, checking and revising vocabulary use, reorganizing essay structure, and correcting mechanical errors (items 813).

Item (8) was designed to look into the student writers' response to peer response on ideas and meaning. It is found that $25 \%$ of the participants strongly agreed and 50\% agreed that they reread their ideas and meanings of an essay. There were, however, $25 \%$ of the students who chose 'uncertain'. This result indicates evidence of the tendency of the student writers to revise their ideas of an essay evaluated by peers.

Moreover, in responding to item (9) about the grammar, most students paid great attention to grammar correction as there were $33 \%$ of participants who strongly agreed and $58 \%$ who agreed that they corrected their grammatical errors in accordance to the peer response. There were, however, $8 \%$ of the participants who chose 'uncertain'. This result reveals that the respondents' tendency to place grammar an important aspect in their essays.

Meanwhile, responding to item (10) about attention to correction symbols, all students gave great care. There were $33 \%$ of the students who strongly agreed and $67 \%$ who agreed that they paid attention to a set of clear corrections and revised their writing accordingly. This finding indicates the importance of response clarity.

Additionally, item (11) was designed to explore student writers' response to peer response regarding the vocabulary use. There were $17 \%$ of respondents who strongly agreed and $50 \%$ who agreed that they checked and revised their vocabulary use. On the other hand, $8 \%$ of respondents chose uncertain regarding the questionnaire statement. This result really indicates the student writers' attention to the peers' evaluation about the use of vocabulary. 
Table 2: The Student-Writers Response to Peer Response

\begin{tabular}{lllll}
\hline Statement & \multicolumn{3}{l}{ Frequency (Percentages) } & \\
\cline { 2 - 5 } & SA & A & U & D SD \\
8) I reread and revise ideas and & $3(25 \%)$ & $6(50 \%)$ & $3(25 \%)$ & \\
meanings of my essay. & & & & \\
9) I correct the grammatical errors of my & $4(33 \%)$ & $7(58 \%)$ & $1(8 \%)$ & \\
essay. & & & \\
10) I pay attention to a set of clear & $4(33 \%)$ & $8(67 \%)$ & \\
corrections and to the symbol and revise & & & \\
my essay. & & & \\
11) I check vocabulary use and revise it. & $2(17 \%)$ & $9(75 \%)$ & $1(8 \%)$ & \\
12) I reorganize the ideas of my essay. & $3(25 \%)$ & $7(58 \%)$ & $2(17 \%)$ & \\
13) I correct mechanical errors. & $4(33 \%)$ & $8(67 \%)$ & \\
\hline
\end{tabular}

In responding to item (12), 25\% of the students strongly agreed and $75 \%$ of them agreed that they reorganized ideas in the essay drafts after peer response activities. There were, however, $17 \%$ of the students who chose uncertain about the statement. The finding tells that the studentwriters were willing to reorganize their idea after according to the given feedback.

Next, item (13) investigated the student writers' response to peer response regarding the mechanical features. There were $33 \%$ of the participants who strongly agreed and $67 \%$ of them who agreed that the student writers corrected their mechanical errors such as spelling, punctuation, etc. The result shows that the writers were willing to correct their mechanical errors such as spelling, punctuation, etc.
To summarize, based on the findings indicated in Table 2, it was obviously showed that the majority of respondents or the student-writers positively responded to peers' feedback of their writings. Even though they gave a high response in the areas of peer feedback for their drafts as revealed in each item, there was a tendency of the student writers to responses to peer response by following the clear correction suggestions and correcting mechanical errors. It is indicated from the total of the questionnaire frequency count of the student-writers response to peer response and percentage equivalent from strongly agreed (SA) and agreed (A) to items (10) and (13), totally $100 \%$ $(n=12)$. The finding clarifies Ting and Qian (2010, p. 95) result that both grammar and mechanics were the most frequently revised elements that can 
contribute to improving the students' essays in terms of fluency and accuracy.

\section{The EFL Students' Expectation from Peer Response}

Table 3 shows the questionnaire frequency count of what studentwriters expect from the peer response and its percentage equivalent. It presents the respondents' score on the writer expectation to peer response on essay drafts.

The analysis of the questionnaire has also focused on specific areas expected by the student writers to be evaluated by reviewers in terms of clarification of ideas and meanings of an essay, grammatical correctness, ideas development, provision of clear correction and review symbols, vocabulary use, essay organization, and mechanical corrections (items 14-20).

Item (14) was designed to look into the student writers' expectancy from peer response outcomes on ideas and meaning. Two students (17\%) strongly agreed and nine students $(75 \%)$ agreed that they expected peers to ask them about their ideas and their meanings of an essay. There was, however, one student $(8 \%)$ who chose 'uncertain'. This result reveals more evidence of the tendency of the student writers to have their ideas of an essay evaluated by peers.

Table 3: The Student-Writers Expectation to Peer Response

\begin{tabular}{|c|c|c|c|c|c|}
\hline \multirow[t]{2}{*}{ Statement } & \multicolumn{5}{|c|}{ Frequency (Percentages) } \\
\hline & SA & A & $\mathrm{U}$ & $\mathbf{D}$ & SD \\
\hline 14) I expect my peer reviewer to ask me about & 2 & 9 & & & \\
\hline ideas and meanings of my essay. & $(17 \%)$ & $(75 \%)$ & $(8 \%)$ & & \\
\hline 15) I expect my peer reviewer to correct the & 3 & 8 & & & \\
\hline grammatical errors in my essay. & $(25 \%)$ & $(67 \%)$ & $(8 \%)$ & & \\
\hline 16) I expect my peer reviewer to give comment & 6 & 6 & & & \\
\hline on ideas and meanings, and extend them. & $(50 \%)$ & $(50 \%)$ & & & \\
\hline 17) I expect my peer reviewer to provide a set of & 4 & 8 & & & \\
\hline clear corrections by giving symbols. & $(33 \%)$ & $(67 \%)$ & & & \\
\hline 18) I expect my peer reviewer to evaluate & 5 & 6 & 1 & & \\
\hline vocabulary and give corrections. & $(42 \%)$ & $(50 \%)$ & $(8 \%)$ & & \\
\hline 19) I expect my peer reviewer to evaluate the & 2 & 9 & & & \\
\hline way to organize ideas of my essay. & $(17 \%)$ & $(75 \%)$ & $(8 \%)$ & & \\
\hline 20) I expect my peer reviewer to give correction & & & & & \\
\hline for mechanical errors. & $(33 \%)$ & $(67 \%)$ & & & \\
\hline
\end{tabular}


Furthermore, in responding to item (15) about the importance of grammar, all participants gave grammar great attention. Three students (25\%) strongly agreed and eight students $(67 \%)$ agreed that peers should correct their grammar. There was, however, one student $(8 \%)$ who chose 'uncertain'. This result reveals that the respondents' tendency to place grammar an important aspect in their essays. It is worth mentioning here that during the interview, many of the respondents expressed their need for more response on grammar correction.

When asked about their expectancy of peer response outcome on ideas expansion and essay development of item (16), six students (50\%) strongly agreed and six students (50\%) agreed that ideas expansion and how to develop an essay are an important aspect to be shared with peers.

Meanwhile, responding to item (17) about the provision of setting clear correction and correction signals, all respondents give great care. Four students (33\%) strongly agreed and eight students $(67 \%)$ agreed that peers should provide clear correction symbols. This is very important in a sense that clear correction clues are deemed to facilitate revision and peer response incorporation. This finding indicates the importance of feedback clarity. This finding indicates the urgent point of peer feedback and confirms the prior research investigated by Salih (2013). The prior research finding revealed when peer response is provided in an ambiguous manner, the required points of peer response incorporation might not be fulfilled.

In addition, item (18) was designed to explore the expectancy of student writers regarding their use of vocabulary items. Five participants (42\%) strongly agreed and six participants (50\%) agreed that peers should evaluate their choice of vocabulary and suggest corrections. On the other hand, there was one student $(8 \%)$ who chose uncertain about the statement. This result indicates the student writers' willingness to share ideas with peers about the use of vocabulary.

In responding to item (19), two students $(17 \%)$ strongly agreed and nine students (75\%) agreed that they expected peers to evaluate the way they organized ideas in the essay drafts. There was, however, one student $(8 \%)$ who chose uncertain with the statement. The respondent looked forward to suggestions on ideas organization and essay structure in peer response. It indicates that idea 
development response should be received from peers.

The study also investigated (item 20) the student writers' expectation from peer response regarding the mechanical features. Four students $(33 \%)$ strongly agreed and eight students $(67 \%)$ agreed that they expected peers to correct their spelling, punctuation, etc. This is also important for polishing essay drafts as asserted by Oshima and Hogue (2007), the emphasis on mechanical correction is one of the aims to polish the drafts of writing.

To conclude, from overall results, it was clear that most of the respondents expected that the feedbacks tap into areas of ideas and meanings, grammar, feedback clarity, vocabulary use, ideas organization of an essay, and mechanical correction respectively.

However, the tendencies of the student-writers' expectations from the peer response are on comments on ideas and meanings, provision of clear correction, and correction on mechanical errors. It is indicated from the total of the questionnaire frequency count of the student-writers' expectation from peer response and its percentage equivalent from strongly agreed (SA) and agreed (A) to items $(16),(17)$ and $(20)$, totally $100 \%(n=12)$.
The findings are almost the same as Salih (2013) reported in his study, but the findings are different in giving the rank in rating. Salih (2013) reported that the student writers have selected grammar as the most important aspect needed to be evaluated by peers; giving it the first rank in rating. However, the results of the current study show that commenting on ideas and meanings, providing clear correction, and correcting mechanical errors are the prime areas of the student-writers expectation to peer response.

\section{CONCLUSION AND SUGGESTION}

This current study investigated the EFL students' performance in and expectation of peer response in writing classroom. Based on the analysis of the results of the questionnaire in this survey research, it was revealed that majority of the EFL students performed and expected peer response in the areas of peer feedback as confirmed in the questionnaire items. However, there were tendencies of their performance and expectation towards peer response. First, in terms of the kind of tasks performed by the student reviewers, they tend to ask about peer' ideas and meanings of an essay. Second, there are tendencies of the student-writers responses to pay attention to clear correction and correcting mechanical 
errors. Third, the student-writers expect that peer responses are commenting on ideas and meanings, providing clear correction, and correcting mechanical errors as well.

This survey research was limited only to investigate what EFL students do in a peer response activities and what they expect from this activities in a writing classroom. Therefore, the author is proposing the following suggestions. Firstly, further studies should explore other various patterns of peer response in writing classroom. Secondly, in the EFL writing teaching, teachers are recommended to encourage peer response because of its power and benefits for the students' writing skills development.

\section{REFERENCES}

Al-Jamal, D. (2009). The impact of peer response in enhancing ninth grader's writing skill. Umm AlQura University Journal of Educational \& Psychologic Sciences, $1(1), 13-40$.

Askew, S. (2000). Feedback for learning. New York: Routledge Falmer.

Bell, J. H. (1991). Using peer response groups in ESL writing classes. TESL Canada Journal/Revue TESL Du Canada, 8(2), 65-70.
Farrah, M. (20120. The impact of peer feedbacks on improving the writing skills among Hebron university students. An-Najah University Journal Research (Humanities), 26(1), 180-210.

Hapsari. (2015). A learner's selfregulated learning in writing. IJEE (Indonesian Journal of English Education), 2(2), 120-131.

Jahin, J. H. (2012). The effect of peer reviewing on writing apprehension and essay writing ability of prospective EFL teachers. Australian Journal of Teacher Education, 37(11), 60-84.

Luchini, P. L. (2010). Evaluating the effectiveness of a complimentary approach to teaching writing skills. International Journal of Language Studies (IJLS), 4(3), 73-92.

Mangelsdorf, K. (1992). Peer reviews in the ESL composition classroom: What do the students think. ELT Journal, 46(3), 274-284.

McKay, S. L. (2008). Researching second language classroom. New Jersey: Lawrence Erlbaum Associates Publishers. 
Miftah, M. Z. (2014). Teaching writing using peer response via facebook. In Erliana, S. \& M. Z. Miftah, (Eds), Proceedings of $2^{\text {nd }}$ International Conference on English Linguistics, Literature, and Education (ELITE): The Multifaceted Dimensions of English Linguistics, Literature, and Education (pp. 157169). Palangka Raya: State Islamic College of Palangka Raya.

Miftah, M. Z. (2015). Enhancing writing skill through writing process approach. Journal on English as a Foreign Language, 5(1), 9-24.

Miftah, M. Z. (2015). Peer response in an Indonesian EFL writing class: A case study. In A. Ridwan \& S. Fiangga (Eds). Proceedings of International Conference on Educational Research and Development (ICERD): Trends and Challenges toward Asian Economic Community (pp. 637-648). Surabaya: State University of Surabaya.

Miftah, M. Z. (2016). Promoting EFL students' abilities in writing definition paragraph through blogging activities. In E. M. Rahayu et al. (Eds). Proceedings of the 63rd TEFLIN International Conference: Creativity and Innovation in Language Materials Development and Language
Teaching Methodology in Asia and Beyond, Book 2 (pp. 370-379). Surabaya: University of PGRI Adi Buana Surabaya.

Mubarak, M. F. (2009). Improving the ability of the third-year students of MA Tarbiyatul Wathon Gresik in writing narrative text through peer feedback (Unpublished Master Thesis). State University of Malang, Malang.

Oshima, A., \& Hogue, A. (2007). Introduction to academic writing ( $3^{\text {rd }}$ ed.). New York: Longman.

Rollinson, P. (2005). Using peer feedback in the ESL writing class. ELT Journal, 59(1), 23-30.

Salih, A. R. A. (2013). Peer response to L2 student writing: Patterns and expectations. English Language Teaching, 6(3), 42-50.

Stevens, D. D. \& Levi, A. (2005). Introduction to rubrics: An assessment tool to save grading time, convey effective feedback and promote student learning. Virginia: Stylus Publishing, LLC.

Tang, G. M. \& Tithecott, J. (1999). Peer response in ESL writing. TESL Canada Journal/La Revue TESL Du Canada, 16(2), 21-38. 
Ting, M. \& Qian, Y. (2010). A case study of peer feedback in a Chinese EFL writing classroom. Chinese Journal of Applied Linguistics (Bimonthly), 33(4), 87-98.

Tuckman, B. W. (1999). Conducting educational research ( $5^{\text {th }}$ ed.). Orlando: Harcourt Brace \& Company.
Wakabayashi, R. (2008). The effect of peer feedback on EFL writing: Focusing on Japanese university students. OnCUE Journal, 2(2), 92110.

Widiati, U. (2003). Training EFL writing students in Indonesia in the use of strategies for peer response (Unpublished Master Thesis). Monash University, Victoria. 